Agro-Science Journal of Tropical Agriculture, Food, Environment and Extension Volume 12 Number 1 January 2013 pp 59 - 65

TSSNIIIY-7455

\title{
EVALUATION OF SOURCES OF ORGANIC MANURE ON THE GROWTH AND YIELD OF GARDEN EGG (SOLANUM SPP.) IN THE SUBHUMID GUINEA SAVANNA AND RAINFOREST BELTS OF NIGERIA
}

\author{
Kekong, M. A ${ }^{1}$ S. A. Ayuba ${ }^{2}$ and A. Ali ${ }^{2}$ \\ ${ }^{1}$ Department of Agronomy, Cross River University of Technology Obubra \\ ${ }^{2}$ Department of Soil Science, University of Agriculture Makurdi.
}

\begin{abstract}
Field experiments were conducted at the Teaching and Research Farms of the University of Agriculture, Makurdi and the Cross River University of Technology, Obubra campus during the 2009 cropping season to study the effect of sources of organic manures on the growth and yield of two cultivars of Garden egg in the subhumid Guinea Savanna and rainforest belts of Nigeria. A factorial combination of Garden egg varieties (Solanum aethiopicum-Gilo and Solanum aethiopicum kumba) and manure sources (0,5,10,20 tha horinga $^{-1}$ mon leaf biomas, 5, 10,15, $t \mathrm{ha}^{-1}$ poultry droppings, 1,2,3 $\mathrm{t} \mathrm{ha}^{-1}$ fertiplus) were laid out in a randomized complete block design $(R C B D)$ in three replications. All organic manure resources significantly $(P<0.05)$ increased the growth and yield of the garden egg cultivars over control. Poultry droppings at $15 \mathrm{th} \mathrm{a}^{-1}$ produce tallest plants, highest number of fruits per plant and highest yield of $9.18 \mathrm{tha}^{-1}$ and $8.65 \mathrm{tha}^{-1}$ respectively for Makurdi and Obubra, this was followed by Moringa $20 \mathrm{th} \mathrm{h}^{-1}$ (7.22 and $6.68 \mathrm{th} \mathrm{h}^{-1}$ ) respectively for Makurdi and Obubra and Fertiplus $3 t h^{-1}$ with yield of 6.78 and $5.77 t h^{-1}$ respectively for Makurdi and Obubra. Moringa $20 t$ hal produce the highest dry matter of the plants. The least fruit number of fruits per plant than Kumba and fruit yield in $t \mathrm{ha}^{-1}$ was higher in Gilo. There was no significant interaction between varieties and manure. Yield of both varieties was higher in Makurdi than Obubra Moringa Oleifera leaf biomas and poultry droppings are promising soil conditioners for optimum production of garden egg.
\end{abstract}

\section{INTRODUCTION}

Garden egg (Solanum Spp), an edible vegetable is widely grown in Nigeria mainly for its immature fruits and leaves, depending on the variety. Leaster and Seck (2004) described the African egg plant as one of the most commonly consumed fruit vegetable in tropical Africa in quantity and value, probably the third after tomato and Onion.

The productivity of tropical soils has been a subject of concern because of its management problems associated with sustainability. Sanchez et al.., (1997) opined that declining soil fertility has been identified as the fundamental cause of declining crop yields in many parts of Africa. In addition to the scarcity and high cost of inorganic fertilizers, Nottidge et al. (2005) stated that chemical fertilizer has not been able to sustain high productivity due to its enhancement of soil acidity, leaching and organic matter degradation.
Organic manure has been found to be biologically efficient in the maintenance of soil fertility which is critical to the sustainability, particularly of tropical fragile soils. The potentials of organic manure for soil fertility restoration, maintenance and sustainability and the negative effect of inorganic fertilizer on soil properties in the long run are well known. Although there is a scientific evidence on increased crop yields due to organic manure application, crop yield response to addition of organic manures in highly variable depending on the type of manure, crop species, climate condition, soil type among other variables. There is need to evaluate organic manure sources for sustainable production of garden egg, a cherished vegetable in Africa and Nigeria particularly. 


\section{MATERIAL AND METHODS}

Location: A field experiment was conducted at the Teaching and Research Farm of the University of Agriculture, Makurdi (Latitude $7^{0}, 45^{\prime} \mathrm{N}$ and Longitude $8^{0} 53^{\prime}$ E) in the Southern Guinea Savanna Zone and the Cross River University of Technology Obubra Campus(Latitude $6^{\circ} 06^{\prime} \mathrm{N}$ and Longitude $8^{0} 18^{\prime}$ E) in the Rainforest zone of Nigeria, during the 2009 cropping season.

Design of experiment: This was factorial in Randomized complete block design (RCBD) consisting of 2 factors: 10 sources of organic manures (M) as $\mathrm{M}_{0}, \mathrm{M}_{1}, \mathrm{M}_{2}, \mathrm{M}_{3}, \mathrm{M}_{4}, \mathrm{M}_{5}, \mathrm{M}_{6}, \mathrm{M}_{7}$, $\mathrm{M}_{8}, \mathrm{M}_{9}$, and 2 varieties of Garden egg: $\mathrm{V}_{1}$, and $\mathrm{V}_{2}$ $\mathrm{M}_{0},=$ control, $\mathrm{M}_{1,}=5$ tha $^{-1}$ moringa leaf, $\mathrm{M}_{2,}=$ $10 \mathrm{t} \mathrm{ha}^{-1}$ moringa leaf, $\mathrm{M}_{3}=20 \mathrm{t} \mathrm{ha}^{-1}$ moringa leaf, $\mathrm{M}_{4}=5 \mathrm{t} \mathrm{ha}^{-1}$ poultry dropping, $\mathrm{M}_{5}=10 \mathrm{t}$ $\mathrm{ha}^{-1}, \mathrm{M}_{6}=15 \mathrm{t} \mathrm{ha}^{-1}$ poultry manure $\mathrm{M}_{7}=1 \mathrm{t} \mathrm{ha}^{-1}$ ? Fertiplus' $\mathrm{M}_{8}=2 \mathrm{t} \mathrm{ha}^{-1}$ 'fertiplus' $\mathrm{M}_{9}, 3 \mathrm{t} \mathrm{ha}^{-1}$ ، Fertiplus while $\mathrm{V}_{1}=$ Gilo and $\mathrm{V}_{2}=$ Kumba. This gave a treatment combination of 20 treatments which were replicated 3 times with each plot size measuring $4 \mathrm{~m} \times 3 \mathrm{~m}\left(12 \mathrm{~m}^{2}\right)$ with an alley of $1 \mathrm{~m}$ as block boundaries and $0.5 \mathrm{~m}$ as plot boundaries and gross experimental plot of $35 \mathrm{~m} \times 38 \mathrm{~m}\left(980 \mathrm{~m}^{2}\right)$ or 0.098 ha.

\section{Nursery, land preparation and planting:}

The nursery was raised on a raised shaded plot and managed through irrigation and insect pests control for 4 weeks in both locations before transplanting in the main field. The main field was cleared and ridged manually. These operations were done in Makurdi; between $8^{\text {th }}-10^{\text {th }}$ July 2009 and Obubra between $11^{\text {th }}-12^{\text {th }}$ July 2009.

\section{Manure application:}

The poultry dropping was obtained from the University of Agriculture and Cross River University of Technology Poultry Farms. Moringa leaf for Makurdi was collected from Zongo village in North bank while in Obubra the moringa leaf was collected from the Obubra prison staff quarter; fertiplus was obtained from STEP-B project of the University of Agriculture Makurdi. The poultry manure and moringa leaf were incorporated into the seed beds two weeks before transplanting of the garden egg seedlings while 'Fertiplus' was incorporated at time of transplanting.

\section{Data collection and Analysis:}

Soil: A composite soil sample was collected at the $0-20 \mathrm{~cm}$ depth from random points for each location before treatments application. The soil sample was air dried and sieved with a $2 \mathrm{~mm}$ sieve and was subjected to standard laboratory analysis as outlined by Udo et al,, (2009).

Plant: Four plants were tagged in each net plot from where plant height, number of branches and number of fruits were taken, 2 plants were cut at ground level from each net plot, ovon dried at a temperature of $100^{\circ} \mathrm{C}$ and weighed to constant weight. The yield from each net plot cumulatively from first harvest to last harvest was extrapolated to yield in tones per hectare. Analysis of variance (ANOVA) for RCBD in factorial was performed on plant growth and yield using Gensta (2005) soft ware. FLSD was calculated for $\mathrm{P}<0.05$. T- test was used to determine location effect on yield.

\section{Result and Discussion \\ Initial Properties of Soil}

Result of physico-chemical analysis of the soils in the two locations and manure analysis (Tables 1 and 2) show the soils at both sites of the experiment were sandy-loam, low in Om, N, P exchangeable bases and $\mathrm{CEC}$, although $\mathrm{OM}$ and CEC were relatively higher in Makurdi than Obubra.

Kekong, M. A S. A. Ayuba and A. Ali

Effect or 1 reatment on Growin and y ieia or Garden Egg

Plant height and number of branches (Tables 3 and 4) shows that at 8 weeks after transplanting (WAT) in Makurdi application of moringa leaf, poultry droppings and 'Fertiplus' did don't affect growth of the garden egg. At 10 WAT, application of poultry manure at 10 and $15 \mathrm{t} \mathrm{ha}^{-1}$, Moringa 20 $\mathrm{t} \mathrm{ha}^{-1}$ and 'Fertiplus' $3 \mathrm{t} \mathrm{ha}^{-1}$ produced tallest plants. This was followed by other manure rates and the least plant height was obtained from the control where no manure was applied. There was no significant $(\mathrm{P}<0.05)$ differences in plant height among the Gilo and Kumba varieties. At 14 WAT, Moringa leaf applied at the rate of $20 \mathrm{t} \mathrm{ha}^{-1}$ poultry dropping 15 and $10 \mathrm{tha}^{-1}$ than $10 \mathrm{tha}^{-1}$ Moringa and least plant height was obtained from the control. In Obubra, plant height of the garden egg varieties was not significantly affected by the manure sources 8 and 10 WAT. But at 14 WAT, poultry droppings applied at the rate of $15 \mathrm{t} \mathrm{ha}^{-1}$, poultry dropping at $10 \mathrm{t} \mathrm{ha}^{-1}$ and 'Fertiplus' $2 \mathrm{t}$ $\mathrm{ha}^{-1} 2 \mathrm{t} \mathrm{ha}^{-1}$ with plant heights of $56.57 \mathrm{~cm}$, $85.63 \mathrm{~cm}$ and $86.07 \mathrm{~cm}$ respectively. The least plant height was recorded in the control. 
Table 1. Physical and Chemical Properties of the Soils at the Experimental Site.

\begin{tabular}{|c|c|c|}
\hline & MAKURDI & OBUBRA \\
\hline SOIL PARAMETERS & 2009 & 2009 \\
\hline Sand $(\mathrm{g} / \mathrm{kg})$ & 874 & 853 \\
\hline Silt $(\mathrm{g} / \mathrm{kg})$ & 84 & 79 \\
\hline Clay $(\mathrm{g} / \mathrm{kg})$ & 42 & 68 \\
\hline texture class & $\mathrm{S} / \mathrm{L}$ & $\mathrm{S} / \mathrm{L}$ \\
\hline $\mathrm{P}^{\mathrm{H}}$ (water) & 6.16 & 5.50 \\
\hline $\mathrm{P}^{\mathrm{H}}(\mathrm{KCL})$ & 5.00 & 4.30 \\
\hline Organic matter & 2.80 & 1.82 \\
\hline Total nitrogen $(\mathrm{g} / \mathrm{kg})$ & 1.0 & 0.8 \\
\hline Available $\mathrm{P} \mathrm{mg} / \mathrm{kg}$ & 5.5 & 3.6 \\
\hline Exch. Ca cmol kg ${ }^{-1}$ & 3.40 & 2.50 \\
\hline Exchange. $\mathrm{Mg} \mathrm{cmol} \mathrm{kg}{ }^{-1}$ & 0.30 & 0.22 \\
\hline Exchange. $\mathrm{Mg} \mathrm{cmol} \mathrm{kg}^{-1}$ & 0.92 & 1.01 \\
\hline Exchange $\mathrm{Na} \mathrm{cmol} \mathrm{kg}{ }^{-1}$ & 0.16 & 0.17 \\
\hline Exchange. Acidity & 2.30 & 2.75 \\
\hline $\mathrm{CEC} \mathrm{cmol} \mathrm{kg}^{-1}$ & 2.3 & 1.7 \\
\hline
\end{tabular}

Table 2: Nutrient Composition of the Organic Manure Sources

\begin{tabular}{lccccccc}
\hline $\begin{array}{c}\text { Manure and location } \\
\text { (Makurdi) }\end{array}$ & $\mathbf{N}$ & $\mathbf{P}$ & $\mathbf{K}$ & $\mathbf{C a}$ & $\mathbf{M g}$ & $\mathbf{N a}$ & Org.C \\
Moringa leaf & 4.10 & 1.21 & 17.1 & 13.6 & 0.12 & 2.19 & 10.8 \\
Poultry manure & 1.80 & 2.4 & 3.2 & 6.2 & 196 & 0.10 & 7.9 \\
(Obubra) & 4.02 & 1.18 & 18.0 & 12.4 & 0.11 & 1.16 & 11.1 \\
Moringa leaf & 1.72 & 2.2 & 2.55 & 7.0 & 1.13 & 0.11 & 8.2 \\
Poultry manure & 4.2 & 3.0 & 2.8 & 9.0 & 1.0 & 0.5 & 37.6 \\
Fertiplus & & & & & & & \\
\hline
\end{tabular}

The number of branches produced by garden egg varieties in response to the manure sources in Makurdi (table 4) show that 'Fertiplus' $3 \mathrm{t} \mathrm{ha}^{-1}, 2$ $\mathrm{t} \mathrm{ha}^{-1}$, poultry dropping $5 \mathrm{t} \mathrm{ha}^{-1}$ and moringa $5 \mathrm{t} \mathrm{ha}$ 1 produced highest number of branches of garden egg and the least branches was obtained from plants in the control. At 10 WAT, the highest number of branches was obtained from plants treated with $15 \mathrm{t} \mathrm{ha}^{-1}$ poultry dropping, $20 \mathrm{t} \mathrm{ha}^{-1}$ moringa and 2-3 $\mathrm{t} \mathrm{ha}^{-1}$ 'Fertplus' and the least number of branches was obtained from the control. At 14 WAT, application of $15 \mathrm{t} \mathrm{ha}^{-1}$ poultry manure produced plants with the highest number of branches (14.00). This was followed by plants treated with $20 \mathrm{t} \mathrm{ha}^{-1}$ moringa (12.50) and then 'Fertiplus' $3 \mathrm{t} \mathrm{ha}^{-1}$ treated plants and the least number of branches was produced by plants in the control. In obubra, ( Table 4) the manure sources did not affect the number of branches of garden egg significantly at 8 WAT neither did the varieties. At $10 \mathrm{WAT}$, the highest number of branches was produced by plants treated with Moringa leaf $20 \mathrm{t}$, ha ${ }^{-1}$ poultry dropping $10-15 \mathrm{t}$ $\mathrm{ha}^{-1}$ and 'Fertiplus' 2-3 $\mathrm{t} \mathrm{ha}^{-1}$. The least number of branches was obtained from the control. At 14 WAT, poultry dropping 10-15 $\mathrm{t} \mathrm{ha}^{-1}$ and Moringa $20 \mathrm{t} \mathrm{ha}^{-1}$ produced the highest number of branches of the garden egg. The least number of branches was obtained from plants in the control. There was no difference significently in the mean number of branches between the varieties Gilo and Kumber. 
Table3: Main Effct of Plant Height (cm) of Garden Egg as Affected by Sources of Organic Manure in Makurdi and Obubra 2009.

\begin{tabular}{|c|c|c|c|c|c|c|c|c|}
\hline \multirow{2}{*}{$\begin{array}{l}\text { TREATMENT } \\
\text { MANURE }\end{array}$} & \multirow{2}{*}{$\begin{array}{c}\text { MAKURDI } \\
\text { 8WAT }\end{array}$} & \multicolumn{7}{|c|}{ OBUBRA } \\
\hline & & \multicolumn{2}{|r|}{ 10WAT } & \multicolumn{2}{|r|}{ 14WAT } & \multirow{2}{*}{$\frac{\text { 8WAT }}{20.65}$} & 10WAT & \multirow{2}{*}{$\frac{\text { 14WAT }}{37.92}$} \\
\hline CONTROL & 21.78 & \multicolumn{2}{|r|}{34.85} & \multicolumn{2}{|r|}{40.38} & & $\frac{\text { 10WAT }}{31.57}$ & \\
\hline MG, 5t/ha & 33.22 & & 48.58 & & 65.72 & 31.05 & 47.05 & 69.15 \\
\hline MG, 10t/ha & 40.07 & & 52.22 & & 77.35 & 37.30 & 50.27 & 77.08 \\
\hline MG, $20 \mathrm{t} / \mathrm{ha}$ & 41.25 & & 59.78 & & 88.52 & 39.27 & 57.80 & 86.57 \\
\hline PD 5t/ha & 38.07 & & 50.53 & & 80.45 & 34.62 & 48.13 & 77.45 \\
\hline PD 10t/ha & 42.27 & & 59.75 & & 87.77 & 40.22 & 57.50 & 85.63 \\
\hline PD 15t/ha & 44.28 & & 62.12 & & 86.08 & 43.08 & 62.68 & 90.15 \\
\hline FPP $1 \mathrm{t} / \mathrm{ha}$ & 29.85 & & 55.30 & & 68.07 & 28.75 & 47.82 & 66.30 \\
\hline FP 2t/ha & 39.52 & & 56.93 & & 83.32 & 31.67 & 54.53 & 81.20 \\
\hline FP 3t/ha & 10.92 & & 60.50 & & 84.05 & 34.82 & 39.50 & 86.07 \\
\hline LSD $(\mathrm{P}<0.05)$ & NS & & 3.09 & & 5.64 & NS & NS & 2.57 \\
\hline \multicolumn{9}{|l|}{ VARIETIES } \\
\hline GILO & 38.27 & 54.88 & 76.98 & 35.72 & 52.37 & 75.95 & & \\
\hline KUMBS & 35.97 & 53.29 & 75.37 & 32.56 & 51.00 & 75.56 & & \\
\hline$\underline{\operatorname{LSD}}(\mathrm{P}<0.05)$ & NS & NS & NS & NS & NS & NS & & \\
\hline \multicolumn{9}{|l|}{ KEY: } \\
\hline MG & Moringa Le & & & & & & & \\
\hline PD & Poultry Dro & & & & & & & \\
\hline FP & Fertiplus $\mathrm{M}_{\mathrm{c}}$ & & & & & & & \\
\hline
\end{tabular}

Table 4: Number of Branches of Garden Egg Varieties as Influenced By Source of Organic Manure (Main Effect) In Makurdi and Obubra, 2009

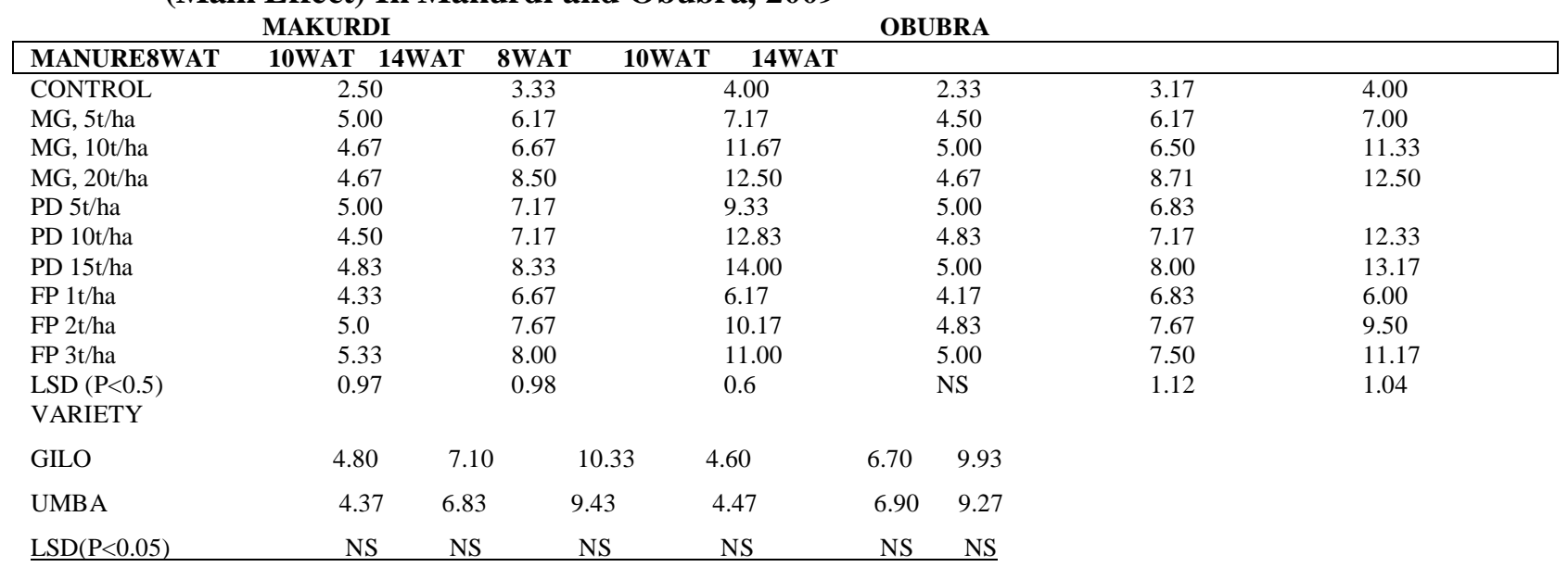

KEY

$\begin{array}{lll}\text { MG } & = & \text { Moringa } \\ \text { PD } & = & \text { Poultry Droppings } \\ \text { FP } & = & \text { Fertiplus }\end{array}$


Kekong, M. A S. A. Ayuba and A. Ali

Table 5: Yield and Yield Components of Garden Egg Varieties as Influenced by Organic Manure Source

\begin{tabular}{|c|c|c|c|c|c|c|c|c|}
\hline \multirow[b]{2}{*}{ Treatment } & Dry Matter g/plant & \multicolumn{2}{|c|}{ No. of Fruits } & \multicolumn{3}{|c|}{ Fruit yield t ha } & \multirow[b]{2}{*}{ Obubra } & \multirow[b]{3}{*}{0.92} \\
\hline & Makurdi & Obubr: & Makurd & di Obuk & & Makurdi & & \\
\hline Control & 58.5 & & 58.3 & & 11.17 & 8.50 & 1.18 & \\
\hline MG, $5 \mathrm{t} / \mathrm{ha}$ & 122.8 & & 118.5 & & 31.67 & 26.5 & 2.42 & 2.78 \\
\hline MG $10 \mathrm{t} / \mathrm{ha}$ & 190.0 & & 183.8 & & 37.33 & $30.1^{\top}$ & 5.47 & 5.77 \\
\hline MG $20 t / h a$ & 205.8 & & 197.5 & & 51.00 & 40.6 & 7.22 & 6.68 \\
\hline PD 5t/ha & 126.5 & & 134.7 & & 41.33 & 37.1 & 4.40 & 4.03 \\
\hline PD 10t/ha & 186.2 & & 172.3 & & 52.83 & $47.1^{\top}$ & 7.28 & 6.62 \\
\hline PD 15t/ha & 200.3 & & 199.8 & & 64.50 & 57.6 & 9.18 & 8.65 \\
\hline FP $1 \mathrm{t} / \mathrm{ha}$ & $1040 .($ & & 96.7 & & 22.82 & 18.6 & 2.86 & 2.18 \\
\hline FP 2t/ha & 128.5 & & 118.2 & & 39.17 & 33.8 & 6.00 & 6.20 \\
\hline FP 3t/ha & 155.3 & & 143.2 & & 50.17 & 43.0 & 6.78 & 5.77 \\
\hline LSD $(\mathrm{P}<0.05)$ & 9.16 & & 18.23 & & 5.04 & 3.18 & 0.47 & 0.67 \\
\hline \multicolumn{9}{|l|}{ Variety } \\
\hline Gilo & 148.9 & 145.5 & 52.40 & 44.67 & 5.89 & 5.39 & & \\
\hline Kumba & 146.7 & 139.1 & 28.00 & 24.00 & 4.67 & 4.65 & & \\
\hline$\underline{\mathrm{LSD}}(\mathrm{P}<0.05$ & NS & NS & 2.26 & 1.42 & 0.21 & 0.67 & & \\
\hline \multicolumn{9}{|l|}{ Key: } \\
\hline MG & Moringa leaf & & & & & & & \\
\hline PD & Poultry Drop & pping & & & & & & \\
\hline FP & Fertiplus Ma & anure & & & & & & \\
\hline
\end{tabular}

Table 6: Location Effect of Fruit Yield of Garden Egg As Affected By Organic Manure Source

\begin{tabular}{lll} 
& \multicolumn{2}{c}{ Fruit Yield t ha $\mathbf{~ h}^{-1}$} \\
& Makurdi A & Obubra B \\
\hline $\mathrm{M}_{\mathrm{o}} \mathrm{V}_{1}$ & 1.17 & 1.00 \\
$\mathrm{M}_{\mathrm{o}} \mathrm{V}_{2}$ & 0.90 & 0.03 \\
$\mathrm{M}_{1} \mathrm{~V}_{1}$ & 2.81 & 3.30 \\
$\mathrm{M}_{1} \mathrm{~V}_{2}$ & 2.03 & 2.27 \\
$\mathrm{M}_{2} \mathrm{~V}_{1}$ & 6.40 & 6.67 \\
$\mathrm{M}_{2} \mathrm{~V}_{2}$ & 4.53 & 4.87 \\
$\mathrm{M}_{3} \mathrm{~V}_{1}$ & 7.97 & 4.20 \\
$\mathrm{M}_{3} \mathrm{~V}_{2}$ & 6.47 & 6.17 \\
$\mathrm{M}_{4} \mathrm{~V}_{1}$ & 4.87 & 4.37 \\
$\mathrm{M}_{4} \mathrm{~V}_{2}$ & 3.93 & 3.70 \\
$\mathrm{M}_{5} \mathrm{~V}_{1}$ & 7.73 & 6.93 \\
$\mathrm{M}_{5} \mathrm{~V}_{2}$ & 6.83 & 6.30 \\
$\mathrm{M}_{6} \mathrm{~V}_{1}$ & 9.87 & 9.17 \\
$\mathrm{M}_{6} \mathrm{~V}_{2}$ & 8.50 & 8.13 \\
$\mathrm{M}_{7} \mathrm{~V}_{1}$ & 3.37 & 2.73 \\
$\mathrm{M}_{7} \mathrm{~V}_{2}$ & 2.37 & 1.63 \\
$\mathrm{M}_{8} \mathrm{~V}_{1}$ & 7.13 & 6.30 \\
$\mathrm{M}_{8} \mathrm{~V}_{2}$ & 6.10 \\
$\mathrm{M}_{9} \mathrm{~V}_{1}$ & 4.87 & 6.23 \\
$\mathrm{M}_{9} \mathrm{~V}_{2}$ & 7.33 & 6.50 \\
$\mathrm{X}$ & 6.23 & 5.05 \\
$\mathrm{SE}$ & 5.28 & \\
\hline
\end{tabular}


Plant dry matter, number of fruits per plant and fruit yield in $\mathrm{t} \mathrm{ha}^{-1}$ is presented in Table 5. Application of $15 \mathrm{t} \mathrm{ha}^{-1}$ poultry dropping and $20 \mathrm{t} \mathrm{ha}^{-1}$ Moringa leaf produced the highest amount of plant dry matter in both Makurdi and Obubra. This was followed by dry matter yield in plant treated with $10 \mathrm{tha}^{-}$ 1 poultry droppings and $10 \mathrm{t} \mathrm{ha}^{-1}$ Moringa leaf. 'fertiplus' $3 \mathrm{t} \mathrm{ha}^{-1}$ ranked third and the least dry matter was obtained in plants in the control. The Gilo and Kumba varieties did not show any statistically different dry matter values. The highest number of fruits was obtained from plants treated with poultry dropping 15 tha $^{-1}$ in both Makurdi and Obubra (Table 5). This was followed in Makurdi by plants treated with poultry dropping $10 \mathrm{tha}^{-1,}$ moringa leaf $20 \mathrm{tha}^{-1}$ and 'Fertiplus' $3 \mathrm{t} \mathrm{ha}^{-1}$. This was followed by other rates and the least fruits number of garden egg was obtained in the control. In Obubra, the highest number of fruits treatment was followed by plants treated with $10 \mathrm{t} \mathrm{ha}^{-1}$ poultry manure, then followed by plants treated with moringa leaf $20 \mathrm{t} \mathrm{ha}^{-1}$ and $3 \mathrm{t} \mathrm{ha}^{-1}$ "Fertiplus ' and the least number of fruits was obtained from control. In both locations, Gilo variety produced higher number of fruits than kumba varieties.

Poultry dropping applied at $15 \mathrm{t} \mathrm{ha}^{-1}$ produced highest fruit yield in both Makurdi and Obubra (9.18 and $8.65 \mathrm{tha}^{-1}$. The least fruits yield was obtained in control plots in both Makurdi and Obubra than the Kumba variety (table 5) and there was no significant interaction between manure source and crop variety. Application of the poultry dropping, moringa leaf and 'fertiplus' significantly produced higher garden egg yield in Makurdi than Obubra (Table 6).

The significant increase in the growth and yield parameters of the garden eggvarieties is a manifestation of the positive imprints of organic manures properties that transform into high fertility status and a confirmation of the high mineralizable nutrient composition of organic manures which was reported by Lombin et al.. (1991); Warman (1986); Bahman and James (1997); Duncan (2005). The response of the crops to these organic manure sources agrees with the assertions of Isitekhle and Osemota (2010) who noted that organic resources are important shortterm suppliers of nutrients as well as for long-term maintenances of soil organic matter. The yield response of garden egg to poultry manure application has been earlier reported by Kekong et al. (2010) on Gilo using poultry dropping upto $15 \mathrm{t} \mathrm{ha}^{-1}$. The increase in growth and yield parameters of garden egg varieties due to Moringa oleifera leaf application agrees with the findings of Booth and wickens (1988) who noted that the high protein biomass of reported Moringa olieifera is suited for use and acts as natural fertilizer while Davis (2000) reported that the use of Moringa oleifera as a green manure significantly improved soil fertility.

The higher yield of Gilo variety than Kumber variety is a genotypic characteristics of the crop between varieties. This yield response difference was reported by Sanginga et al. (2000) who stated that some crop genotypes tend to have greater need for nutrient and are often more responsive to nutrient input.

The higher yield of garden egg varieties in Makurdi than Obubra could be attributed to variation in soil properties (table 1). Chude (1998) reported that Cross River State soils have low $\mathrm{P}$ and exchangeable cations except $\mathrm{K}$ and that exchangeable cations are higher in the Nigeria Savanna than Rainforest belt.

\section{CONCLUSION}

The manurial potentials of Moringa oleifera, poultry droppings and 'fertiplus' investigated in this study were found to be efficient in the maintenance of soil fertility for good garden egg production. Application of these manure especially, the higher rates increased garden egg yield significantly over the control. Poultry manure $\left(15 \mathrm{t} \mathrm{ha}^{-1}\right)$ and moringa $20 \mathrm{t} \mathrm{ha}^{-1}$ as an alternative to poultry manure are good sources of plant nutrients for the optimum production of garden egg in the Nigerian Guinea savanna and Rainforest belts.

\section{REFERENCES}

Bahmann, F, and F.P.James (1988) composted and non-composited manure application to conventional and no - tillage systems, corn yield and nitrogen uptake. Agronomy Journal 9:818

Booth, F. E. M. and G. E. Wickens (1988). Non timber uses of selected arid zone trees and shrubs in Africa. FAO Conservation Guide, Rome pp 92-101.

Chude, V.O. (1998) Understanding Nigeria soils and their fertility management for subtainable Agriculture. Inangural Lecture delivered at ABU, Zaria on Thursday Nov. 26. 1998. Inaugural lecture series 13 . 
Kekong, M. A S. A. Ayuba and A. Ali

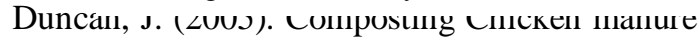
WUS cooperative Extension, King county master Gardener and cooperative Extension livestock Advisor. $12 \mathrm{pp}$

Genstat (2008). Genstat Release, 4.2DE (PC/Windows XP) Copy right 2005, Lawes Agricultural Trust (Rothanstal) Experimental Station) Discovering Edt 2.

Isitehale, H.H.E and I.O. Osemwota (2010) Residual effect of poultry manure and NPK fertilizer on soil physical properties in the forest and derived savanna soils of Edo State, Nigeria. Soil Science Journal of Nigeria 20 (2) 26-34.

Kekong,M. A., S. A. Ayuba and A. Ali (2010). Effect of cow dung and poultry droppings on soil chemical properties and yield of garden egg (Solanum spp) in the sub humid guinea savanna and rainforest belts of Nigeria. Nigerian Journal of Soil Science 20 (1) 97-104.

Lester, R. N. and seck (2004) solanum aethiopicum L. In: Grubben, G.J.H and Denton O. A (Editors). Plant Resource of Tropical Africa 2. vegetables PROTA foundation wageningen. Nether lands/ Backhuys Pub. Leiden, Netherlands/ CTA, Wageningen, Netherlands Pp 488-493.

Lombin, L.O., J. ADepetu and K.A. Ayotade (1991). Complemetary use of organic manure and inorganic fertilizers in Arable crop production. Organic fertilizer in the Nigeria Agriculture: present allu ıuture. Proceedings of a National Organic fertilizer seminar, Kaduna, Nigeria March 26-27, 1991.

Nottidge, D. O. S. O. Ojeniyi and D. S. Asawalam (2005). Comparative effect of plant residues and N. P. K. fertilizer on nutrient status and yield of maize (Zea Mays L) in a humid Ultisol. Nigeria Journal of Soil Science Vol. 15:1-8.

Sanchez, P.A., K.D. Shepherd, M.J. Sonle, F.M. place, R.J. Buresh, A.M. Izac, A.U, Mokwunye F.R. Kwesiga, C.G. Nderitu and P.L Woome (1997) Soil Fertility Replenishment in Africa: An Investment in Natural Resource Capital 1-46 Pp. In: R.J. Buresh, P.A. Sanchez and F. Calhoun (eds) Replenishing Soil Fertility in Africa Soil Science Society of America Special. Publication no. 51 Madison, Wisconsin.

Sanginga, N., O. Lyasse and B. B. Singh (2000) Phosphorus use, efficiency and nitrogen balance of cowpea breeding lines in a low $\mathrm{P}$ soil of the derived savanna zone in West Africa. Plant and Soil Journal $220: 119-128$.

Udo, E. J., T. O. Ibia, J. O. Ogunwale, A. O. Ano and I. Esu (2009), Manual of Soil, Plant and Water Analysis, Sibon looks Ltd. Lagos. Pp 183

Warman, P. R. (1986). The effect of fertilizer, chicken manure and daily manure on Timothy yield, tissue composition and soil fertility. Agricultural Wastes 8: 289-298. 